Tomasz J. Dabrowski

Szkoła Glówna Handlowa w Warszawie

\title{
Wykorzystanie stron internetowych w komunikowaniu polityki społecznej odpowiedzialności przez spółki publiczne notowane na GPW w Warszawie*
}

\section{THE ROLE OF WEBSITES IN COMMUNICATING CSR POLICY BY PUBLIC COMPANIES LISTED ON THE WARSAW STOCK EXCHANGE}

\begin{abstract}
Przedsiębiorstwa, angażujac się $w$ działania z zakresu CSR, moga generować korzystne dla siebie zachowania interesariuszy $i$ budować reputację. $Z$ drugiej strony niska świadomość interesariuszy dotyczaca tych dziatań $i$ ich nieufność stanowiq główne przeszkody w maksymalizowaniu korzyści dla przedsiębiorstw. Rodzi to potrzebe skutecznej komunikacji, która zwiększałaby tę świadomość $i$ niwelowała nieufność. Celem badań przedstawionych $w$ tym artykule byto określenie, w jaki sposób spótki notowane na Giełdzie Papierów Wartościowych $w$ Warszawie wykorzystuja swoje strony internetowe do komunikowania dziatań z zakresu CSR. Badania oparto na analizie stron internetowych i zamieszczonych na nich dokumentów. Gtówne wyniki wskazuja, że najważniejszym czynnikiem różnicujacym wykorzystanie stron internetowych w komunikacji CSR była wielkość przedsiębiorstwa.
\end{abstract}

Słowa kluczowe: społeczna odpowiedzialność biznesu, komunikacja, Internet, spółki publiczne, interesariusze

JEL Codes: M14, M39, D83

Wstęp

Komunikowanie polityki społecznej odpowiedzialności stanowi dla przedsiębiorstw szczególne wyzwanie. Związane jest ono ze zróżnicowaniem odbiorców komunikatów dotyczących tej sfery, różnorodnością odnoszących się do niej treści oraz mnogością kanałów komunikacji, którymi przekaz może docierać do odbiorcy. Wyzwanie to wynika także $\mathrm{z}$ wyjściowej postawy wielu odbiorców nastawionych sceptycznie do tego typu komunikacji, łączących ją ze zjawiskiem wybielania (greenwashing), czy niewielkiego zainteresowania części interesariuszy sferą społecznej odpowiedzialności biznesu i ich generalnie niskiego poziomu wiedzy w tym zakresie. Dodatkowo, przedsiębiorstwa zajmują się komunikowaniem polityki CSR od stosunkowo niedawna i mają na tym polu znacznie mniej doświadczeń, niż w komunikacji związanej z budowaniem skojarzeń dotyczących ich zdolności do działania i realizowania zadań charakterystycznych dla jednostki gospodarczej. Próby wykorzystywania wiedzy

*Artykuł powstał w ramach badań statutowych dotyczących Zarządzania respektującego wartości w koncepcji rozwoju integralnego (humanistycznego), realizowanych pod kierunkiem dr hab. Magdaleny MikołajekGocejny, prof. SGH (nr badania KNOP/S17/02/17). 
i umiejętności zdobytych w jednym obszarze do rozwijania komunikacji odnoszącej się do zupełnie innych zagadnień w wielu przypadkach kończą się niepowodzeniem.

Komunikacja związana ze społeczną odpowiedzialnością biznesu stanowi materię nową nie tylko dla przedsiębiorstw, ale również dla badaczy. Zwraca się uwagę na fragmentację badań $\mathrm{z}$ tego zakresu i różnorodność perspektyw, $\mathrm{z}$ których problematyka ta jest analizowana, a jednocześnie na rosnące zainteresowanie, jakim się ona cieszy ${ }^{1}$. Dokonując przeglądu literatury przedmiotu Golob i in. ${ }^{2}$ zidentyfikowali główne obszary tematyczne badań obejmujące: ujawnianie informacji (strategie, narzędzia komunikacji, media, oczekiwania interesariuszy), proces komunikacji oraz jej skutki z punktu widzenia przedsiębiorstw i konsumentów. Badania, których wyniki przedstawiono $\mathrm{w}$ artykule mieszczą się $\mathrm{w}$ pierwszym $\mathrm{z}$ wymienionych obszarów. Mają zarówno walor praktyczny, odnosząc się do kwestii stanowiących istotne wyzwanie dla przedsiębiorstw, jak i poznawczy, wzbogacając wiedzę dotyczącą wykorzystania przez podmioty gospodarcze własnych stron internetowych w komunikowaniu swojej polityki społecznej odpowiedzialności.

\section{Znaczenie polityki społecznej odpowiedzialności i jej komunikowanie}

Społeczna odpowiedzialność biznesu może być rozpatrywana z różnych perspektyw. Począwszy od lat 90 . XX w. w literaturze i badaniach z tego zakresu silnie obecny jest nurt akcentujący perspektywę ekonomiczną. W obrębie tego nurtu rozpatrywane są różnego typu korzyści, jakie niesie dla przedsiębiorstw odpowiednio zaprojektowana polityka społecznej odpowiedzialności oraz analizowane są związki między prowadzeniem tej polityki a wynikami finansowymi ${ }^{3}$. Wśród korzyści zwraca się uwagę zarówno na te, które mają charakter endogeniczny, jak i na takie, które odnoszą się do sfery relacji organizacji $\mathrm{z}$ otoczeniem. Do korzyści wewnętrznych można zaliczyć wzrost identyfikacji pracowników $\mathrm{z}$ przedsiębiorstwem ${ }^{4}$ oraz zmniejszenie ryzyka nadużyć wynikające ze zwiększenia roli etyki w kształtowaniu kultury organizacyjnej. Korzyści zewnętrzne obejmują zaś wzrost atrakcyjności podmiotu wśród potencjalnych pracowników ${ }^{6}$, poprawę oceny przedsiębiorstwa i jego produktów ${ }^{7}$ oraz zwiększenie (w pewnych warunkach) ich atrakcyjności dla klientów ${ }^{8}$ a także silniejsze

${ }^{1}$ Golob U., Verk N., Ellerup-Nielsen A., Thomsen C., Elving W.J.L., Podnar K., The communicative stance of CSR: reflections on the value of CSR communication, „Corporate Communications: An International Journal” 2017, Vol. 22, No. 2.

${ }^{2}$ Golob U., Podnar K., Elving W.J., Ellerup Nielsen A., Thomsen C., Schultz F., CSR communication: quo vadis?, „Corporate Communications: An International Journal” 2013, Vol. 18, No. 2.

${ }^{3}$ Carroll A.B., Shabana K.M., The Business Case for Corporate Social Responsibility: A Review of Concepts, Research and Practice, „International Journal of Management Reviews”2010, Vol. 12, No. 1.

${ }^{4}$ Peloza J., Papania L., The Missing Link Between Corporate Social Responsibility and Financial Performance: Stakeholder Salience and Identification. „Corporate Reputation Review” 2008, Vol. 11, No. 2.

${ }^{5}$ Treviño L.K., Weaver G.R., Gibson D.G., Toffler B.L., Managing ethics and legal compliance: What works and what hurts, "California Management Review" 1999, Vol. 41, No. 2.

${ }^{6}$ Turban D.B., Greening D.W., Corporate social performance and organizational attractiveness to prospective employees, "Academy of Management Journal" 1997, Vol. 40, No. 3.

${ }^{7}$ Brown T.J., Dacin P.A., The Company and the Product: Corporate Associations and Consumer Product Responses, ,Journal of Marketing” 1997, Vol. 61, No. 1.

${ }^{8}$ Sen S., Bhattacharya C.B., Does Doing Good Always Lead to Doing Better? Consumer Reactions to Corporate Social Responsibility, ,Journal of Marketing Research” 2001, Vol. 38, No. 2. 
zaangażowanie emocjonalne konsumentów prowadzące w konsekwencji do intencji zakupu $^{9}$, wzrost poczucia satysfakcji u klientów ${ }^{10}$ i podwyższenie się poziomu ich zaufania $^{11}$. Dodatkowo, podnosi się kwestię wpływu społecznej odpowiedzialności na przewagę konkurencyjną ${ }^{12}$ oraz na reputację przedsiębiorstwa ${ }^{13}$.

Szerokie spektrum korzyści związanych z polityką społecznej odpowiedzialności, jakie są udziałem prowadzących ją przedsiębiorstw znajduje swoje odzwierciedlenie w osiaganych przez te podmioty wynikach finansowych. Potwierdzają to zarówno rezultaty badań przeglądowych, obejmujących metaanalizę licznych uzyskanych wcześniej wyników ${ }^{14}$, jak i studia empiryczne dotyczące występowania związków między polityką CSR, jej elementami lub oceną a sytuacją finansową przedsiębiorstw rozpatrywaną w ujęciu księgowym bądź rynkowym. Przedmiotem analizy były między innymi relacje między działaniami w zakresie ochrony środowiska naturalnego i aktywnością prospołeczną a zmianami wartości rynkowej przedsiębiorstwa ${ }^{15}$, między poziomem wydatków na dobroczynność a przyszłymi przychodami ${ }^{16}$, między tego typu wydatkami a rynkową stopą zwrotu skorygowaną o ryzyko ${ }^{17}$, między zmianą oceny polityki społecznej odpowiedzialności podmiotu, skutkującą jego włączeniem do indeksu etycznego lub wykluczeniem go $\mathrm{z}$ niego a różnymi zmiennymi kształtującymi wartość rynkową przedsiębiorstwa ${ }^{18}$.

Przedstawione dotychczas rozważania dowodzą dużego znaczenia polityki społecznej odpowiedzialności, która gdy jest odpowiednio zaprojektowana stanowi dla przedsiębiorstwa źródło korzyści rynkowych, reputacyjnych i finansowych. Rodzi się pytanie, czy podobnie istotna jest komunikacja związana $\mathrm{z}$ tą polityką. Jest to pytanie

\footnotetext{
${ }^{9}$ Pérez R.C., Effects of Perceived Identity Based on Corporate Social Responsibility: The Role of Consumer Identification with the Company, „Corporate Reputation Review” 2009, Vol. 12, No. 2.

${ }^{10}$ Luo X., Bhattacharya C.B., Corporate Social Responsibility, Customer Satisfaction, and Market Value, „Journal of Marketing” 2006, Vol. 70, No. 4.

${ }^{11}$ Pivato S. Misani N., Tencati A., The Impact of Corporate Social Responsibility on Consumer Trust: The Case of Organic Food, „Business Ethics: A European Review”2008, Vol. 17, No. 1.

${ }^{12}$ Porter M.E., Kramer M.R., Creating Shared Value. How to reinvent capitalism - and unleash a wave of innovation and growth, „Harvard Business Review” 2011, January-February.

${ }^{13}$ Brammer S., Pavelin S., Building a good reputation, „European Management Journal” 2004, Vol. 22, No. 6; Siltaoja M.E., Value Priorities as Combining Core Factors between CSR and Reputation - A Qualitative Study, „Journal of Business Ethics” 2006, Vol. 68, No. 1; Soppe A.B.M., Schauten M.B.J., Soppe J. and Kaymak U., Corporate Social Responsibility Reputation (CSRR): Do Companies Comply to their Raised CSR Expectations?, „Corporate Reputation Review” 2011, Vol. 14, No. 4.

14 Margolis D., Walsh J.P., Misery Loves Companies: Rethinking Social Initiatives by Business, „Administrative Science Quarterly” 2003, Vol. 48; Orlitzky M., Schmidt F.L., Rynes S.L., Corporate social and financial performance: A metaanalysis, „Organization Studies” 2003, Vol. 24, No. 3.

${ }^{15}$ Von Arx U., Ziegler A., The Effect of CSR on Stock Performance: New Evidence for the USA and Europe, „Quantitative Finance” 2014, Vol. 14, No. 6.

${ }^{16}$ Lev B., Petrovits C., Radhakrishnan S., Is doing good good for you? How corporate charitable contributions enhance revenue growth, „Strategic Management Journal” 2010, Vol. 31, No. 2.

${ }^{17}$ Brammer S., Millington A.I., Does it pay to be different? an analysis of the relationship between corporate social and financial performance „Strategic Management Journal” 2008, Vol. 29, No. 12.

${ }^{18}$ Consolandi C., Jaiswal-Dale A., Poggiani E., Vercelli A., Global Standards and Ethical Stock Indexes: The Case of the Dow Jones Sustainability Stoxx Index, „Journal of Business Ethics” 2009, Vol. 87, No. 1; Ramchander S., Schwebach R.G., Staking K., The informational relevance of corporate social responsibility: evidence from DS400 index reconstitutions, „Strategic Management Journal” 2012, Vol. 33, No. 3; Adamska A., Dąbrowski T.J., Do Investors Appreciate Information about Corporate Social Responsibility? Evidence from the Polish Equity Market „InzinerineEkonomika-Engineering Economics” 2016, Vol. 27, No. 4.
} 
o tyle znaczące, że komunikacja tego typu wcale nie musi być pozytywnie postrzegana. Jak już bowiem sygnalizowano, przynajmniej część odbiorców ma do niej stosunek negatywny, traktując ją jako przejaw manipulacji nastawionej na wybielanie, czy upiększanie obrazu przedsiębiorstwa (window dressing). Poszukując odpowiedzi na pytanie o znaczenie komunikacji odnoszącej się do polityki CSR podmiotu warto rozpatrzyć je na trzech płaszczyznach. Pierwsza obejmuje komunikację jako element samej polityki społecznej odpowiedzialności. W przypadku takich składowych tej polityki, jak programy etyczne, mające służyć kształtowaniu bardziej wrażliwej etycznie kultury organizacyjnej, dialog z interesariuszami, społeczne kampanie informacyjne, czy projekty z zakresu cause-related marketingu, komunikacja stanowi immanentną część działań związanych $\mathrm{z}$ danym elementem polityki CSR i bez niej polityka w tym obszarze nie mogłaby być realizowana.

Druga płaszczyzna dotyczy komunikacji mającej na celu przekazywanie informacji o inicjatywach z zakresu społecznej odpowiedzialności podejmowanych przez przedsiębiorstwo i ich rezultatach. Prezentowany jest pogląd, że „bez komunikacji nieważne, jakiego rodzaju i ile inicjatyw podejmuja przedsiębiorstwa, wpływ CSR na ich postrzeganie przez interesariuszy będzie zerowy, bądź nawet negatywny"19. Wskazuje się również, że komunikacja dotycząca sfery CSR wpływa na wizerunek, reputację i wiarygodność podmiotu ${ }^{20}$. Komunikacji przypada istotna rola informacyjna i edukacyjna polegająca nie tylko na upowszechnianiu wiedzy na temat działań i dokonań podmiotu, ale także wyjaśnianiu motywów oraz tłumaczeniu znaczenia realizowanych inicjatyw i ich wpływu na sytuację różnych grup interesariuszy. Dzięki temu są możliwe właściwa ocena tych inicjatyw przez interesariuszy i redukowanie poziomu ich nieufności wobec działań prowadzonych przez przedsiębiorstwo w ramach jego polityki CSR.

Trzecia płaszczyzna związana jest natomiast $\mathrm{z}$ rolą komunikacji jako autonomicznego sygnału wskazującego na podejście podmiotu do polityki społecznej odpowiedzialności i jej komunikowania oraz stopień zaangażowania, jakie w obydwu tych sferach przejawia organizacja. Przedsiębiorstwa dość często traktują społeczną odpowiedzialność biznesu i związaną $\mathrm{z}$ nią komunikację jako obszary działań symbolicznych, czyli takich które „zmierzają do osiagnięcia celu bez angażowania znaczących zasobów" ${ }^{\text {21 }}$. Działania te należy odróżnić od działań substancjalnych, które są wymierne i wymagają „widocznego wydatkowania zasobów”22. O ile te pierwsze w sferze komunikacji mają ograniczone znaczenie, o tyle te drugie są istotne, bowiem sygnalizują wysoki poziom zaangażowania i stanowią podstawę oceny przedsiębiorstwa wpływającej na zachowania interesariuszy. Dobrym przykładem w tym zakresie mogą

\footnotetext{
${ }^{19}$ Pérez A., Corporate reputation and CSR reporting to stakeholders: Gaps in the literature and future lines of research, „Corporate Communications: An International Journal” 2015, Vol. 20, No. 1, s. 16

${ }^{20}$ Pfau M., Haigh M.M., Sims J., Wigley S., The Influence of Corporate Social Responsibility Campaigns on Public Opinion, „Corporate Reputation Review” 2008, Vol. 11, No. 2.

21 Mahon J.F., Corporate Reputation: A Research Agenda Using Strategy and Stakeholder Literature, „Business and Society” 2002, Vol. 41, No. 4, s. 419.

${ }^{22}$ Galbreath J., How does corporate social responsibility benefit firms? Evidence from Australia, „European Business Review” 2010, Vol. 22, No. 4, s. 417.
} 
być wyniki badań wskazujące na wpływ takich działań komunikacyjnych, jak publikowanie raportów społecznej odpowiedzialności na wartość podmiotu ${ }^{23}$.

Biorąc pod uwagę wszystkie trzy przedstawione płaszczyzny można przyjąć, że komunikacja dotycząca polityki CSR przedsiębiorstwa ma nie mniejsze znaczenie niż sama polityka, jaką w tej sferze prowadzi organizacja.

\section{Proliferacja przekazu dotyczącego polityki społecznej odpowiedzialności przedsiębiorstwa}

Przedsiębiorstwa nieustannie komunikują się z różnymi grupami interesariuszy starając się kształtować swój pozytywny obraz. Gros tej komunikacji zawiera przekaz dotyczący zdolności do działania, a tylko niewielka część ukierunkowana jest na rozpowszechnianie przesłania związanego ze sferą społecznej odpowiedzialności. Grono odbiorców tych dwóch przekazów pokrywa się jedynie częściowo, a wyjściowa postawa w stosunku do każdego z nich jest inna - w przypadku przekazu odnoszącego się do polityki CSR znacznie bardziej sceptyczna. Wszystko to sprawia, że proliferacja przekazu związanego z polityką społecznej odpowiedzialności przedsiębiorstwa odbywa się w inny sposób, z wykorzystaniem bardziej różnorodnych kanałów komunikacji.

Kanały komunikacji służące rozpowszechnianiu przekazu dotyczącego polityki CSR podmiotu można podzielić na niepowiązane i powiązane z przedsiębiorstwem, a samą komunikację na jednostopniową lub dwustopniową. Głównym kanałem komunikacji niepowiązanym z przedsiębiorstwem są massmedia. W zależności od formy współpracy z nimi podmiot gospodarczy zachowuje większą lub mniejszą kontrolę nad przekazem - większa (w zasadzie pełna) występuje w odniesieniu do reklamy, mniejsza w przypadku działań z zakresu PR. Innym kanałem, najczęściej niepowiązanym z przedsiębiorstwem, są punkty sprzedaży. Mogą być one wykorzystywane jako miejsce rozpowszechniania informacji na temat proekologicznej lub prospołecznej aktywności podmiotu związanej z prowadzonymi kampaniami społecznymi lub realizowanymi programami cause-related marketingu. Ten ostatni instrument marketingu społecznego daje zresztą szczególnie szerokie możliwości komunikacyjne obejmujące łączenie działań przedsiębiorstwa (reklamy $\mathrm{w}$ massmediach, aktywności $\mathrm{z}$ zakresu PR, umieszczania materiałów $\mathrm{w}$ punktach sprzedaży, oznakowywania produktów, aktywności na własnych stronach internetowych, czy w portalach społecznościowych) z działaniami partnerów włączanych do współpracy w ramach programu (najczęściej są to organizacje pozarządowe) i beneficjentów, na rzecz których gromadzone są fundusze $e^{24}$.

Do kanałów komunikacji zależnych od przedsiębiorstwa najpowszechniej używanych w proliferacji przekazu dotyczącego polityki społecznej odpowiedzialności należą własne strony internetowe podmiotu oraz raporty CSR (określane też niekiedy mianem raportów zrównoważonego rozwoju). Wśród największych przedsiębiorstw

\footnotetext{
${ }^{23}$ Carnevale C., Mazzuca M., Sustainability Report and Bank Valuation: Evidence from European Stock Markets, „Business Ethics: A European Review” 2014, Vol. 23, No. 1.

24 Dąbrowski T.J., Cause-related marketing w kreowaniu i komunikowaniu polityki społecznej odpowiedzialności biznesu, „Marketing i Rynek”2011, No. 3.
} 
globalnych ponad $95 \%$ wykorzystuje pierwszy z tych kanałów ${ }^{25}$ i ponad $90 \%$ drugi ${ }^{26}$. Kanały te mają cały szereg zalet decydujących o ich popularności - nie generują bardzo wysokich kosztów, pozwalają przedsiębiorstwu zachować całkowitą kontrolę nad przekazem, umożliwiają dotarcie $\mathrm{z}$ nim do różnych grup interesariuszy i ułatwiają dostarczenie im ważnych informacji dotyczących zaangażowania podmiotu, wywieranego przez niego pozytywnego wpływu, motywacji kryjących się za prospołecznymi, czy proekologicznymi działaniami oraz obrazujących zgodność tych działań z profilem przedsiębiorstwa. Skutkiem przekazywania informacji tego typu jest zmniejszanie się sceptycyzmu interesariuszy wobec polityki społecznej odpowiedzialności podmiotu ${ }^{27}$. Dodatkowo, własne strony internetowe i raporty dają możliwość w miarę swobodnego kształtowania prezentowanych treści, nie ograniczając ich zakresu, co pozwala na przedstawianie faktów i danych zwiększających konkretność i szczegółowość przekazu. Te cechy przekazu odnoszącego się do działań ze sfery CSR zwiększają siłę jego oddziaływania i podnoszą efektywność w budowaniu reputacji przedsiębiorstwa $^{28}$.

Obok własnych stron internetowych i raportów ważnymi kanałami komunikowania polityki społecznej odpowiedzialności podmiotu są media społecznościowe i pracownicy. W przypadku mediów społecznościowych, takich jak Facebook, większe znaczenie mają strony korporacyjne, niż strony poświęcone konkretnym inicjatywom realizowanym wramach tej polityki, bowiem przekaz zawarty na stronach korporacyjnych mocniej wpływa na reputację w zakresie CSR, jaką cieszy się podmiot ${ }^{29}$. $\mathrm{Z}$ kolei pracownicy odgrywają ważną rolę ze względu na swój status wiarygodnego źródła informacji. Jako kanał komunikacji powinni być jednak rozpatrywani w szerszym kontekście . Z jednej strony bowiem są oni odbiorcami przekazu dotyczącego polityki społecznej odpowiedzialności przedsiębiorstwa trafiającego do nich $\mathrm{w}$ ramach komunikacji wewnętrznej z drugiej zaś stanowią nadawców tego przekazu w odniesieniu do interesariuszy zewnętrznych ${ }^{30}$. Dodatkowo pracownicy mogą być również instrumentem polityki CSR chociażby poprzez swoje zaangażowanie w wolontariat pracowniczy. Oprócz mediów społecznościowych i pracowników niekiedy jako kanał komunikowania wybranych elementów polityki prospołecznej bądź prośrodowiskowej przedsiębiorstwa wykorzystywane są opakowania jego produktów. Jest to najczęściej związane z posługiwaniem się przez dany podmiot takimi instrumentami, jak wspominany już cause-related marketing.

Źródłem przekazu dotyczącego polityki CSR przedsiębiorstwa może być ono samo lub podmioty przez niego inspirowane, ale mogą też nim być organizacje i osoby nie pozostające pod wpływem działań komunikacyjnych danej jednostki gospodarczej.

25 Smith K.T., Alexander J., Which CSR-Related Headings Do Fortune 500 Companies Use on Their Websites?, „Business Communication Quarterly” 2013, Vol. 76, No. 2.

${ }^{26}$ KPMG, The road ahead. The KPMG Survey of Corporate Responsibility Reporting 2017.

${ }^{27} \mathrm{Du}$ S., Bhattacharya C.B., Sen S., Maximizing Business Returns to Corporate Social Responsibility (CSR): The Role of CSR Communication, „International Journal of Management Reviews” 2010, Vol. 12, No. 1.

${ }^{28}$ Berens G., van Rekom J., How Specific Should Corporate Communication Be?, in: Facets of Corporate Identity, Communication and Reputation, T.C. Melewar (red.), Routledge, New York 2008.

${ }^{29}$ Lee S.Y., How can companies succeed in forming CSR reputation?, „Corporate Communications: An International Journal" 2016, Vol. 21, No. 4.

${ }^{30}$ Birth G., Illia L., Lurati F., Zamparini A., Communicating CSR: practices among Switzerland's top 300 companies, „Corporate Communications: An International Journal” 2008, Vol. 13, No. 2 
Taki całkowicie niezależny przekaz bywa związany $\mathrm{z}$ oceną polityki społecznej odpowiedzialności poszczególnych podmiotów dokonywaną przez instytucjonalnych mandatariuszy, jakimi są agencje zajmujące się między innymi screeningiem etycznym na potrzeby inwestorów, organizacje pozarządowe, czy media lub z rozprzestrzenianiem informacji przez trudne do zidentyfikowania źródła. W pierwszym przypadku komunikat może mieć charakter syntetyczny i być zawarty w ratingu (np. włączeniu spółki do indeksu etycznego, bądź wykluczenie jej z niego) albo w rankingu, może też przybrać bardziej rozbudowaną postać analizy zamieszczonej w raporcie, reportażu lub innej formie wypowiedzi medialnej, w drugim zaś z reguły związany jest z pogłoską (word of mouth).

\section{Zakres wykorzystania korporacyjnych stron internetowych w komunikowaniu polityki społecznej odpowiedzialności przez spółki publiczne w Polsce - metodyka i wyniki badań}

Badania dotyczące wykorzystania korporacyjnych stron internetowych w komunikowaniu różnych elementów polityki społecznej odpowiedzialności przedsiębiorstwa były już realizowane, zarówno na świecie ${ }^{31}$, jak i w Polsce ${ }^{32}$. Celem badań prezentowanych poniżej było określenie zakresu i sposobu wykorzystywania korporacyjnych stron internetowych w komunikowaniu polityki CSR przez spółki publiczne, których akcje notowane są na rynku regulowanym GPW w Warszawie. $\mathrm{W}$ badaniach skoncentrowano się na trzech grupach podmiotów: spółkach $\mathrm{z}$ indeksu WIG20 (skład indeksu na dzień 21.03.2018 r.), spółkach z indeksu mWIG40 (skład indeksu na dzień 23.03.2018 r.) i spółkach z indeksu sWIG80 (skład indeksu na dzień 23.03.2018 r.). Wybór spółek publicznych podyktowany był takimi ich cechami jak szerokie grono interesariuszy, czy konieczność sprostania wyższym standardom w zakresie poziomu transparentności. Poza tym zwraca się także uwagę na większe zainteresowanie działalnością takich podmiotów przejawiane przez media i opinię publiczną. Wszystkie te czynniki sprzyjają przywiązywaniu przez spółki publiczne większej wagi do sfery społecznej odpowiedzialności biznesu i komunikowania swojej polityki w tym zakresie oraz rosnącemu zainteresowaniu tą polityką ze strony otoczenia. Podstawowe pytania badawcze, na które starano się uzyskać odpowiedzi dotyczyły popularności wykorzystywania korporacyjnych stron internetowych w komunikowaniu polityki społecznej odpowiedzialności oraz elementów tej polityki obecnych w przekazie. Badanie nie dotyczyło natomiast rzeczywistych działań prowadzonych przez przedsiębiorstwa - nie obejmowało weryfikacji informacji prezentowanych przez spółki.

Badaniami objęto łącznie 140 podmiotów. Analizie poddano ich korporacyjne strony internetowe oraz zawarte na nich dokumenty (kodeksy, raporty, opisy strategii itd.). Analiza ta miała na celu uzyskanie odpowiedzi na dwa pytania: czy spółka wykorzystuje swoją stronę internetową w komunikowaniu polityki społecznej odpowiedzialności przedsiębiorstwa oraz jaki jest zakres komunikowania tej polityki.

\footnotetext{
${ }^{31}$ Smith K.T., Alexander J., op. cit.

${ }^{32}$ Krzemień M., Piekalski G., Największe polskie firmy a społeczna odpowiedzialność biznesu, Raport z badania, Screening Centrum CSR.PL, 2012.
} 
Zakres ten mierzony był obecnością na stronie informacji odnoszących się ogólnie do sfery CSR lub bardziej szczegółowo do różnych elementów konstytuujących politykę w tej sferze. Zestaw mierników obejmował więc:

- obecność w serwisie korporacyjnym sekcji, w której publikowane były informacje poświęcone społecznej odpowiedzialności przedsiębiorstw lub dowolnemu elementowi polityki w tym zakresie,

- obecność na stronie internetowej opisu sformalizowanej, przyjętej przez władze spółki strategii CSR, dokumentu, który taką strategię zawierał, bądź informacji, że taka strategia została przyjęta,

- obecność na stronie internetowej informacji dotyczącej istnienia w strukturze organizacyjnej przedsiębiorstwa jednostki zajmującej się CSR i kanału komunikacji umożliwiającego bezpośredni kontakt z konkretnym, wskazanym pracownikiem tej jednostki,

- obecność na stronie kodeksu etycznego (zbioru zasad, kodeksu dobrych praktyk, kodeksu compliance, bądź innego odpowiadającego im dokumentu) lub jego opisu,

- obecność na stronie raportu społecznej odpowiedzialności lub odnośnika do niego,

- obecność na stronie lub w innych zamieszczonych na niej dokumentach informacji o sporządzeniu raportu według wytycznych GRI,

- obecność na stronie lub w innych zamieszczonych na niej dokumentach informacji dotyczącej dialogu z interesariuszami,

- obecność na stronie opisu polityki wobec dostawców, uwzględniającej kryteria CSR lub dokumentu (np. kodeksu), który by taką politykę zawierał, bądź był jej świadectwem,

- obecność na stronie internetowej lub w zamieszczonych na niej dokumentach opisu polityki bądź działań prowadzonych wobec społeczności lokalnej,

- obecność na stronie internetowej lub w zamieszczonych na niej dokumentach informacji dotyczących polityki środowiskowej bądź działań podejmowanych $\mathrm{w}$ tym zakresie,

- obecność na stronie internetowej lub w zamieszczonych na niej dokumentach opisu polityki dobroczynności bądź działań prowadzonych w tej sferze,

- obecność na stronie internetowej lub w zamieszczonych na niej dokumentach informacji na temat wolontariatu pracowniczego.

Badane spółki różniły się pod względem swojego podejścia do wykorzystania korporacyjnych stron internetowych $\mathrm{w}$ komunikowaniu polityki społecznej odpowiedzialności. Podstawowym czynnikiem różnicującym to podejście okazały się rozmiary przedsiębiorstwa. Jest to widoczne między innymi w postaci odsetka spółek z poszczególnych indeksów, które posługiwały się swoimi stronami internetowymi w komunikowaniu tego typu polityki. W przypadku podmiotów największych, należących do indeksu WIG20 obecność w serwisie korporacyjnym najpowszechniej występującego elementu, czyli sekcji w której publikowane były informacje poświęcone społecznej odpowiedzialności przedsiębiorstwa, zaobserwowano w $90 \%$ spółek. W segmencie spółek średnich z indeksu mWIG40 odsetek ten spadał do nieco ponad $62 \%$, a w grupie spółek małych należących do indeksu sWIG80 malał jeszcze bardziej, wynosząc $31 \%$. Zjawisko to można wyjaśnić wskazując, że wykazywanie 
zaangażowania w sferze CSR przez duże podmioty gospodarcze ma większy wpływ na ich reputację, niż wykazywanie takiego zaangażowania przez podmioty mniejsze ${ }^{33}$.

Biorąc pod uwagę ogół badanych spółek wykorzystujących korporacyjne strony internetowe $\mathrm{w}$ komunikowaniu swojej polityki społecznej odpowiedzialności, elementem najpowszechniej występującym w serwisie była, jak już zauważono, sekcja $\mathrm{z}$ informacjami poświęconymi tej polityce - zaobserwowano ją $\mathrm{w}$ około $48 \%$ przypadków. Nieco mniej popularne było publikowanie informacji poświęconych polityce środowiskowej, które znalazły się w $42 \%$ serwisów korporacyjnych oraz danych odnoszących się do polityki dobroczynności, pojawiających się na $40 \%$ stron tego typu. Kolejnymi, pod względem częstości występowania, były informacje dotyczące kodeksów etycznych, raportowania i posiadania sformalizowanej strategii CSR. Kodeksy etyczne zamieściło na swojej stronie internetowej $26 \%$ spółek, a raporty $20 \%$ (ale tylko w $17 \%$ spółek były to raporty opracowane zgodnie z wytycznymi GRI). Podobny odsetek ( $20 \%$ podmiotów) komunikował swoją strategię CSR. Badane przedsiębiorstwa przywiązywały natomiast mniejszą wagę do przekazu odnoszącego się do takich składowych polityki społecznej odpowiedzialności, jak wolontariat pracowniczy, dialog $\mathrm{z}$ interesariuszami, polityka wobec społeczności lokalnych czy uwzględnianie kryteriów CSR we współpracy $\mathrm{z}$ dostawcami. Informacje na temat pierwszego z tych elementów obecne były w serwisach korporacyjnych $14 \%$ spółek, a dane odnoszące się do każdego $\mathrm{z}$ pozostałych trzech tylko w nieco niższym odsetku przypadków (13,5\%). Najrzadziej spółki komunikowały istnienie w przedsiębiorstwie struktur odpowiedzialnych za sferę CSR - tego typu dane znalazły się na stronach internetowych jedynie $8 \%$ podmiotów.

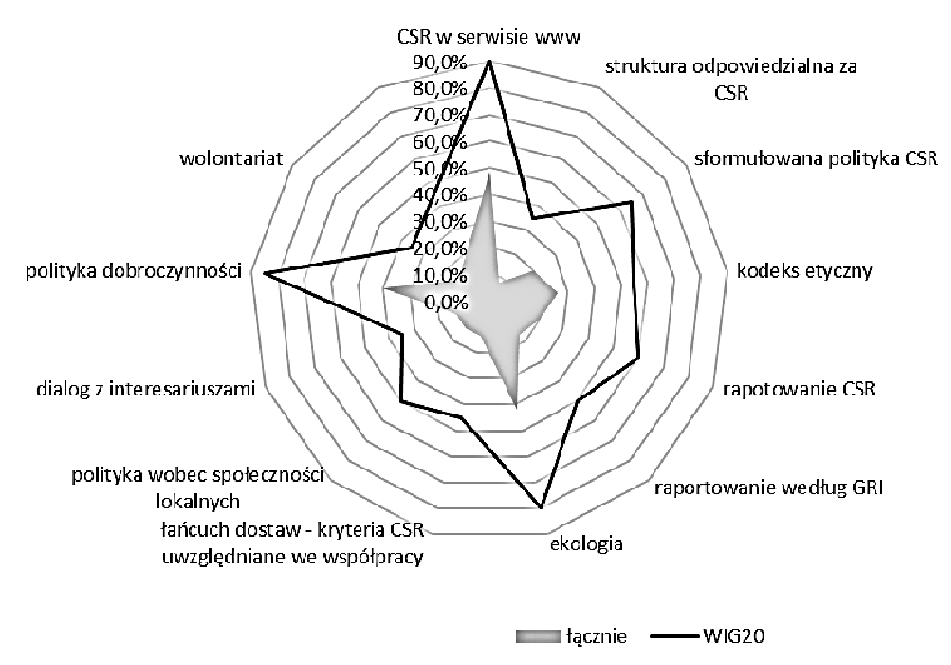

Wykres 1. Komunikowanie polityki CSR przez spółki z indeksu WIG20 na tle ogółu podmiotów komunikujących tę politykę za pomocą korporacyjnej strony internetowej Źródło: opracowanie własne.

${ }^{33}$ Brammer S., Pavelin S., op. cit. 
Po dokonaniu analizy pozwalającej na rozpoznanie całościowego obrazu wykorzystywania przez badane spółki korporacyjnych serwisów internetowych w komunikowaniu ich polityki społecznej odpowiedzialności, podobną analizę przeprowadzono oddzielnie w odniesieniu do spółek należących do każdego z indeksów. Porównanie wyników otrzymanych w całej populacji $\mathrm{z}$ wynikami uzyskanymi w spółkach dużych, średnich i małych, umożliwiło lepsze zrozumienie specyfiki zachowań podmiotów wchodzących w skład każdej z tych grup. W przypadku spółek z indeksu WIG20 najważniejszą cechą wyróżniającą okazało się ich większe zaangażowanie $\mathrm{w}$ komunikowanie każdego $\mathrm{z}$ uwzględnionych $\mathrm{w}$ pomiarze elementów konstytuujących politykę CSR. Jest to dobrze widoczne na wykresie 1.

Obok tego najbardziej zauważalnego wyróżnika można w przypadku spółek dużych wskazać także na inne ich cechy charakterystyczne. Podmioty te przywiązywały nieco większą wagę do komunikowania polityki dobroczynności niż polityki środowiskowej. Przypisywały też większe znaczenie posiadaniu sformalizowanej strategii CSR i jej prezentowaniu na stronie internetowej oraz informowaniu o swojej polityce wobec społeczności lokalnych. Za mniej istotne uznawały natomiast komunikowanie dotyczące kodeksu etycznego i wolontariatu pracowniczego.

Spółki średnie wyróżniał z kolei silniejszy nacisk kładziony na propagowanie przekazu odnoszącego się do ich zaangażowania $w$ wolontariat pracowniczy. Dodatkowo, podmioty te intensywniej wykorzystywały korporacyjne strony internetowe do informowania o swoich kodeksach etycznych i inicjatywach związanych $\mathrm{z}$ troską o środowisko naturalne, natomiast w mniejszym stopniu niż ogół badanych przedsiębiorstw komunikowały uwzględnianie kryteriów CSR w zarządzaniu łańcuchem dostaw. Obrazują to dane przedstawione na wykresie 2.

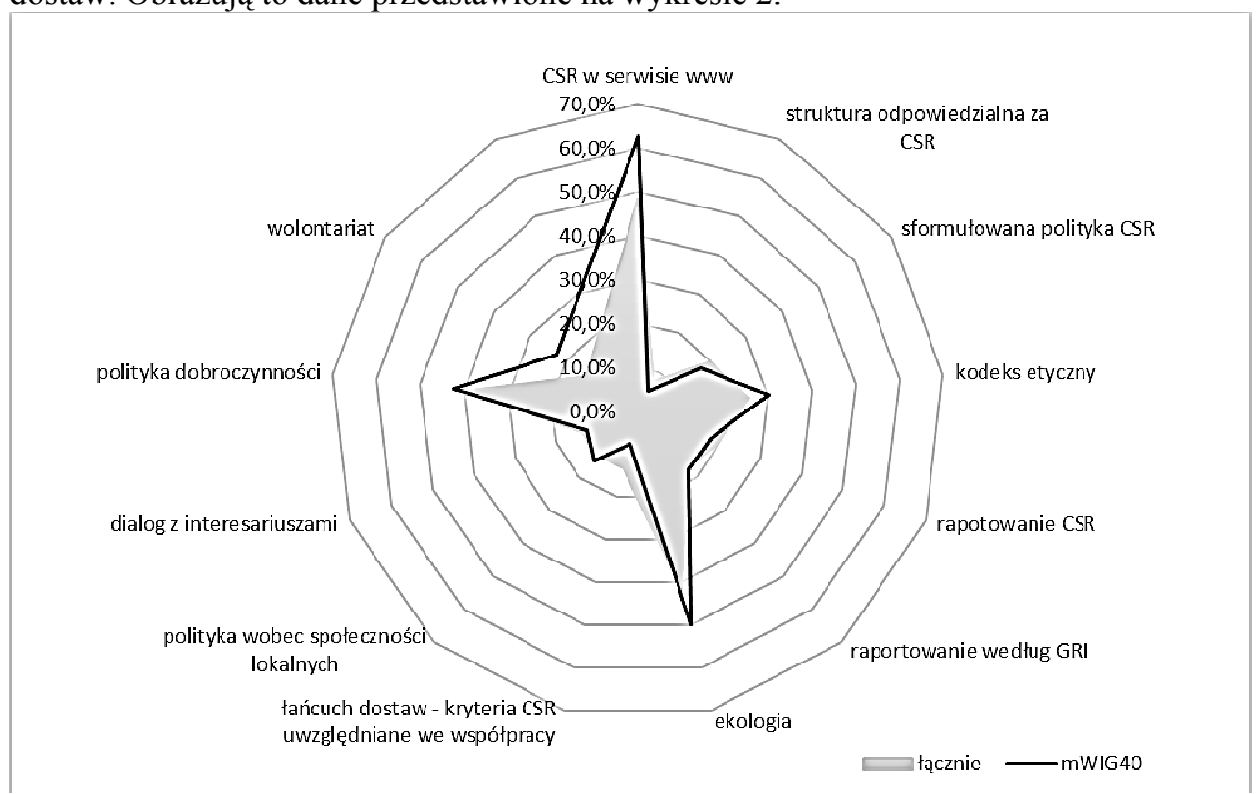

Wykres 2. Komunikowanie polityki CSR przez spółki z indeksu mWIG40 na tle ogółu podmiotów komunikujących tę politykę za pomocą korporacyjnej strony internetowej Źródło: opracowanie własne. 
Cechą charakterystyczną spółek $\mathrm{z}$ indeksu sWIG80 było najmniejsze zaangażowanie $\mathrm{w}$ komunikowanie branych pod uwagę $\mathrm{w}$ pomiarze elementów składowych polityki społecznej odpowiedzialności przedsiębiorstwa. Ponadto spółki te przypisywały mniejsze znaczenie informowaniu o swojej polityce wobec społeczności lokalnych oraz prezentowaniu inicjatyw w zakresie wolontariatu pracowniczego. Relatywnie lepiej natomiast radziły sobie z wykorzystywaniem korporacyjnych stron internetowych do propagowania przekazu dotyczącego dialogu prowadzonego $\mathrm{z}$ interesariuszami i uwzględniania kryteriów CSR $\mathrm{w}$ doborze partnerów w łańcuchu dostaw. Specyfikę tę obrazują dane widoczne na wykresie 3.

Przedstawione zróżnicowanie spółek publicznych pod względem ich podejścia do wykorzystania korporacyjnych stron internetowych w komunikowaniu różnych przejawów polityki społecznej odpowiedzialności tych podmiotów można uzasadnić w wieloraki sposób. Po pierwsze, większa widoczność spółek dużych, z których część funkcjonuje we wrażliwych reputacyjnie sektorach (energetyka, wydobycie i przetwórstwo surowców, bankowość) wymusza na nich bardziej znaczące zaangażowanie środowiskowe i społeczne sprawiając, że prowadzą one szerszy wachlarz działań w tym zakresie i komunikują to. Po drugie, większa aktywność spółek dużych może wynikać z nacisku konkurencyjnego ${ }^{34}$. W przypadku tego typu podmiotów realizowanie polityki CSR obejmującej całe spektrum inicjatyw, instrumentów $i$ adresatów stanowi bowiem element międzynarodowego standardu.

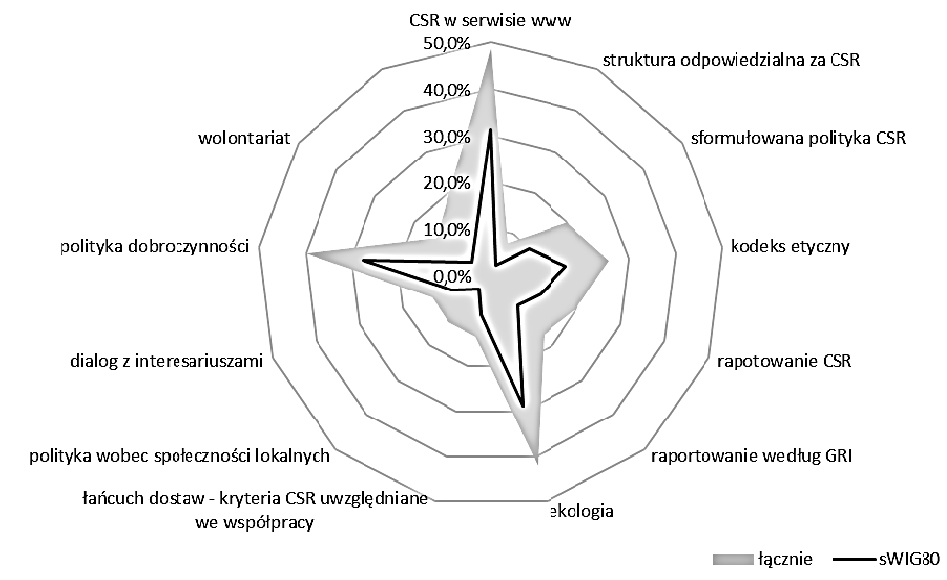

Wykres 3. Komunikowanie polityki CSR przez spółki z indeksu sWIG80 na tle ogółu podmiotów komunikujących tę politykę za pomocą korporacyjnej strony internetowej Źródło: opracowanie własne.

Konformizm nakazuje więc dopasować się do tego standardu, co pozwala uniknąć groźby delegitymizacji, utraty społecznego przyzwolenia na działanie (social licence to operate) i znalezienia się pod pręgierzem opinii publicznej. Po trzecie, jak już

${ }^{34}$ Bertels S., Peloza J., Running Just to Stand Still? Managing CSR Reputation in an Era of Ratcheting Expectations, „Corporate Reputation Review”, 2008, Vol. 11, No. 1. 
sygnalizowano, spółki duże odnoszą z działań w sferze CSR większe korzyści reputacyjne. Może stanowić to dodatkową motywację dla tych podmiotów do prowadzenia bardziej widocznej polityki społecznej odpowiedzialności. Po czwarte, duże spółki ze względu na swoje rozmiary mają szersze grono interesariuszy i wywierają silniejszy wpływ na ich sytuację. Rodzi to uzasadnione, dalej idące oczekiwanie ze strony interesariuszy, odpowiedzią na które jest bardziej rozbudowana polityka CSR przedsiębiorstwa i dotycząca jej komunikacja. Po piąte wreszcie, duże spółki dysponują większymi zasobami. Daje to nie tylko większe możliwości w zakresie prowadzenia polityki społecznej odpowiedzialności, ale także wymusza szersze i bardziej intensywne przekazywanie informacji na jej temat. Poświęcanie na komunikację zbyt małych zasobów sygnalizowałoby bowiem, że sfera CSR traktowana jest przez przedsiębiorstwo jako obszar działań jedynie symbolicznych, odzwierciedlając niski poziom zaangażowania podmiotu $\mathrm{w}$ inicjatywy prospołeczne i prośrodowiskowe.

W przypadku spółek średniej wielkości i małych, komunikowanie polityki CSR może być mniej intensywne, ponieważ podmioty te nie podlegają tak silnej presji zewnętrznej, ani też nie muszą angażować tak dużych zasobów, aby sygnalizować odpowiedni poziom aktywności społecznej. Dlatego też ich korporacyjne strony internetowe rzadziej zawierają przekaz poświęcony polityce społecznej odpowiedzialności, a zakres prezentowanych na nich informacji jest zazwyczaj węższy.

\section{Podsumowanie}

Kwestia społecznej odpowiedzialności przedsiębiorstw może być rozpatrywana $\mathrm{z}$ różnych perspektyw: etycznej, społecznej, czy politycznej. W artykule przyjęto perspektywę ekonomiczną i zarządczą, koncentrując się na korzyściach płynących z prowadzenia polityki CSR oraz znaczeniu jej komunikowania. Biorąc pod uwage, że korporacyjne strony internetowe stanowią jeden z głównych kanałów tej komunikacji zbadano, w jaki sposób kanał ten jest wykorzystywany przez spółki publiczne notowane na GPW w Warszawie. Uzyskane wyniki wskazuja, że spółki te różnią się pod względem stopnia wykorzystania korporacyjnych stron internetowych $\mathrm{w}$ proliferacji przekazu dotyczącego ich polityki CSR. Podstawowym czynnikiem różnicującym okazały się rozmiary podmiotu - najczęściej i w najszerszym zakresie polityka ta była komunikowana przez spółki duże, należące do indeksu WIG20, a najrzadziej informowały i niej spółki małe, należące do indeksu sWIG80.

Przeprowadzone badania koncentrowały się na identyfikacji występowania w serwisach internetowych spółek informacji na temat różnych elementów polityki CSR, nie obejmowały natomiast bardziej szczegółowego rozpoznania sposobu prezentowania tych informacji. Dalsze badania mogłyby więc dotyczyć analizy treści pozwalającej ustalić długość zamieszczanych na stronach komunikatów, określić ich zawartość semantyczna, czy zidentyfikować stosowane w nich techniki impression management.

\section{Bibliografia}

Adamska A., Dąbrowski T., Zarzqdzanie ryzykiem reputacji w banku, „Finanse. CzasopismoKomitetuNauk o Finansach PAN" 2010, No. 1(2). 
Adamska A., Dąbrowski T.J., Do Investors Appreciate Information about Corporate Social Responsibility? Evidence from the Polish Equity Market „Inzinerine Ekonomika-Engineering Economics" 2016, Vol. 27, No. 4.

Berens G., van Rekom J., How Specific Should Corporate Communication Be?, in: Facets of Corporate Identity, Communication and Reputation, T.C. Melewar (red.), Routledge, New York 2008.

Bertels S., Peloza J., Running Just to Stand Still? Managing CSR Reputation in an Era of Ratcheting Expectations, „Corporate Reputation Review”, 2008, Vol. 11, No. 1.

Birth G., Illia L., Lurati F., Zamparini A., Communicating CSR: practices among Switzerland's top 300 companies, „Corporate Communications: An International Journal” 2008, Vol. 13, No. 2.

Brammer S., Millington A.I., Does it pay to be different? an analysis of the relationship between corporate social and financial performance „Strategic Management Journal” 2008, Vol. 29, No. 12.

Brammer S., Pavelin S., Building a good reputation, „European Management Journal” 2004, Vol. 22, No. 6.

Brown T.J., Dacin P.A., The Company and the Product: Corporate Associations and Consumer Product Responses, „Journal of Marketing” 1997, Vol. 61, No. 1.

Carnevale C., Mazzuca M., Sustainability Report and Bank Valuation: Evidence from European Stock Markets, „Business Ethics: A European Review” 2014, Vol. 23, No. 1.

Carroll A.B., Shabana K.M., The Business Case for Corporate Social Responsibility: A Review of Concepts, Research and Practice, „International Journal of Management Reviews” 2010, Vol. 12, No. 1.

Consolandi C., Jaiswal-Dale A., Poggiani E., Vercelli A., Global Standards and Ethical Stock Indexes: The Case of the Dow Jones Sustainability Stoxx Index, „Journal of Business Ethics” 2009, Vol. 87, No. 1.

DąbrowskiT.J., Cause-related marketing $w$ kreowaniu $i$ komunikowaniu polityki społecznej odpowiedzialności biznesu, „Marketing i Rynek” 2011, No. 3.

$\mathrm{Du}$ S., Bhattacharya C.B., Sen S., Maximizing Business Returns to Corporate Social Responsibility (CSR): The Role of CSR Communication, „International Journal of Management Reviews" 2010, Vol. 12, No. 1.

Fombrun C.J., Gardberg N.A., Barnett M.L., Opportunity platforms and safety nets: corporate citizenship and reputational risk, „Business and Society Review” 2000, Vol. 105, No. 1.

Galbreath J., How does corporate social responsibility benefit firms? Evidence from Australia, „European Business Review” 2010, Vol. 22, No. 4.

Golob U., Podnar K., Elving W.J., Ellerup Nielsen A., Thomsen C., Schultz F., CSR communication: quo vadis?, „Corporate Communications: An International Journal” 2013, Vol. 18, No. 2.

Golob U., Verk N., Ellerup-Nielsen A., Thomsen C., Elving W.J.L., Podnar K., The communicative stance of CSR: reflections on the value of CSR communication, „Corporate Communications: An International Journal” 2017, Vol. 22, No. 2.

KPMG, The road ahead. The KPMG Survey of Corporate Responsibility Reporting 2017.

Krzemień M., Piekalski G., Największe polskie firmy a społeczna odpowiedzialność biznesu, Raport z badania, Screening Centrum CSR.PL, 2012.

Lee S.Y., How can companies succeed in forming CSR reputation?, „Corporate Communications: An International Journal" 2016, Vol. 21, No. 4.

Lev B., Petrovits C., Radhakrishnan S., Is doing good good for you? How corporate charitable contributions enhance revenue growth, „Strategic Management Journal” 2010, Vol. 31, No. 2.

Luo X., Bhattacharya C.B., Corporate Social Responsibility, Customer Satisfaction, and Market Value, „Journal of Marketing” 2006, Vol. 70, No. 4. 
Mahon J.F., Corporate Reputation: A Research Agenda Using Strategy and Stakeholder Literature, „Business and Society” 2002, Vol. 41, No. 4.

Margolis D., Walsh J.P., Misery Loves Companies: Rethinking Social Initiatives by Business, „Administrative Science Quarterly” 2003, Vol. 48.

OrlitzkyM., Schmidt F.L., Rynes S.L., Corporate social and financial performance: $A$ metaanalysis, „Organization Studies” 2003, Vol. 24, No. 3.

Peloza J., Papania L., The Missing Link Between Corporate Social Responsibility and Financial Performance: Stakeholder Salience and Identification. „Corporate Reputation Review” 2008, Vol. 11, No. 2.

Pérez A., Corporate reputation and CSR reporting to stakeholders: Gaps in the literature and future lines of research, „Corporate Communications: An International Journal” 2015, Vol. 20, No. 1.

Pérez R.C., Effects of Perceived Identity Based on Corporate Social Responsibility: The Role of Consumer Identification with the Company, „Corporate Reputation Review” 2009, Vol. 12, No. 2.

Pfau M., Haigh M.M., Sims J., Wigley S., The Influence of Corporate Social Responsibility Campaigns on Public Opinion, „Corporate Reputation Review” 2008, Vol. 11, No. 2.

Pivato S. Misani N., Tencati A., The Impact of Corporate Social Responsibility on Consumer Trust: The Case of Organic Food, „Business Ethics: A European Review” 2008, Vol. 17, No. 1.

Porter M.E., Kramer M.R., Creating Shared Value. How to reinvent capitalism - and unleash a wave of innovation and growth, „Harvard Business Review” 2011, January-February.

Ramchander S., Schwebach R.G., Staking K., The informational relevance of corporate social responsibility: evidence from DS400 index reconstitutions, „Strategic Management Journal” 2012, Vol. 33, No. 3.

Sen S., Bhattacharya C.B., Does Doing Good Always Lead to Doing Better? Consumer Reactions to Corporate Social Responsibility, „Journal of Marketing Research” 2001, Vol. 38, No. 2.

Siltaoja M.E., Value Priorities as Combining Core Factors between CSR and Reputation - A Qualitative Study, „Journal of Business Ethics” 2006, Vol. 68, No. 1.

Smith K.T., Alexander J., Which CSR-Related Headings Do Fortune 500 Companies Use on Their Websites?, „Business Communication Quarterly” 2013, Vol. 76, No. 2.

Soppe A.B.M., Schauten M.B.J., Soppe J. and Kaymak U., Corporate Social Responsibility Reputation (CSRR): Do Companies Comply to their Raised CSR Expectations?, „Corporate Reputation Review" 2011, Vol. 14, No. 4.

Treviño L.K., Weaver G.R., Gibson D.G., Toffler B.L., Managing ethics and legal compliance: What works and what hurts, "California Management Review" 1999, Vol. 41, No. 2.

Turban D.B., Greening D.W., Corporate social performance and organizational attractiveness to prospective employees, "Academy of Management Journal" 1997, Vol. 40, No. 3.

Von Arx U., Ziegler A., The Effect of CSR on Stock Performance: New Evidence for the USA and Europe, „Quantitative Finance” 2014, Vol. 14, No. 6.

\section{Summary}

Companies, by engaging in Corporate Social Responsibility (CSR) activities, can generate favorable stakeholder behaviors and build up their corporate reputations. On the other hand, stakeholders' low awareness of these activities, and their lack of confidence in corporations, create major obstacles in gaining maximum benefits for these companies. This gives rise to a need for effective CSR communication. The purpose of the research presented in this paper was to identify how companies listed on the Warsaw Stock Exchange use their websites to communicate CSR activities. The research was based on the analysis of company documents. The main results show that company size was the most important factor differentiating CSR communication. 
Key words: corporate social responsibility, communication, internet, public companies, stakeholders

JEL Codes: M14, M39, D83

Informacja o autorze:

dr hab. Tomasz J. Dąbrowski, prof. SGH

Instytut Zarządzania Wartością

Zakład Marketingu Wartości

Szkoła Główna Handlowa w Warszawie

Al. Niepodległości 162

02-554 Warszawa

e-mail: tomasz.dabrowski@sgh.waw.pl

ORCID: 0000-0002-0594-6642 